\title{
Pengaruh Penambahan Roti Afkir Dalam Pakan Terhadap Kualitas Telur Ayam Ras
}

\author{
Christina $^{1 *}$, Hidayat $^{1 *}$ dan Warnoto ${ }^{1}$ \\ ${ }^{1}$ Jurusan Peternakan, Fakultas Pertanian, Universitas Bengkulu JI. WR. Supratman Kel. Kandang Limun \\ Kec. Muara Bangkahulu Bengkulu 38371A \\ *Penulis korespondensi : hidayat@unib.ac.id
}

Artikel ini diterima (received): 22 Agustus 2020; dinyatakan disetujui (accepted): 28 Oktober 2020; terbit (published): 27 November 2020. Artikel ini dipublikasi secara daring pada https://ejournal.unib.ac.id/index.php/buletin pt/index

\begin{abstract}
Abstrak
Penelitian ini bertujuan untuk mengevaluasi penggunaan tepung roti afkir dalam ransum tehadap kualitas telur ayam ras. Penelitian ini dilaksanakan pada bulan Oktober-Desember 2019 di Kota Bengkulu. Rancangan penelitian yang digunakan yaitu Rancangan Acak Lengkap (RAL) 5 perlakuan dan 10 ulangan. Perlakuan terdiri dari P0 : ransum kontrol $0 \%$ tepung roti afkir, P1 : $10 \%$ tepung roti afkir, P2 : 20\% tepung roti afkir, P3 : 30\% tepung roti afkir, P4 : 40\% tepung roti afkir. Variabel yang diamati adalah berat telur, warna yolk, indeks kuning telur, indeks putih telur, haugh unit, tebal kerabang, dan kedalaman rongga udara. Data yang diperoleh dianalisis dengan sidik ragam (ANOVA) jika berpengaruh nyata $(\mathrm{P}<0,05)$ maka dilakukan uji lanjut Duncan Multiple Range Test (DMRT). Hasil penelitian menunjukan bahwa, penggunaan tepung roti afkir level 10\%, 20\%, 30\%, dan $40 \%$ dalam ransum berpengaruh tidak nyata terhadap berat telur $(P>0,05)$, indeks yolk, indeks albumein, Haugh Unit, tebal kerabang, dan rongga udara, namun berpengaruh nyata $(P<0,05)$ terhadap warna yolk dengan skor cenderung menurun. Dapat disimpulkan bahwa penggunaan tepung roti afkir dalam ransum dari level $20 \%$ atau lebih dapat menurunkan warna yolk, tetapi tidak menurunkan berat telur, indeks indeks yolk, indeks albumen, haugh unit, tebal kerabang dan ronggga udara.
\end{abstract}

Kata kunci: Ayam ras petelur, tepung roti afkir, kualitas telur.

\section{Pendahuluan}

Ternak unggas merupakan ternak yang dapat dibudidayakan untuk tujuan produksi sebagai penghasil pangan sumber protein hewani bagi masyarakat dan memiliki nilai ekonomis bagi manusia yang memeliharanya. Jenis ternak unggas yang memberikan keuntungan antara lain yaitu ayam, itik, kalkun, merpati dan puyuh. Ternak unggas merupakan aset nasional yang turut menunjang kehidupan sosial dan ekonomi masyarakat. Seiring dengan meningkatnya permintaan konsumen terhadap kebutuhan-kebutuhan yang berkaitan dengan produk peternakan membuktikan bahwa usaha peternakan dewasa ini mengalami kemajuan. Diantara produk produk tersebut unggas memegang peranan yang sangat penting, karena digemari dan banyak dikenal oleh masyarakat. Sarwono (2001) menyatakan bahwa telur merupakan produk peternakan yang sangat memberikan kontribusi besar bagi terpenuhinya kecukupan gizi masyarakat. Telur umumnya digemari masyarakat karena harganya terjangkau, kaya akan zat gizi, rasanya lezat dan dapat diolah menjadi berbagai jenis makanan. Jenis telur yang paling banyak dikonsumsi masyarakat adalah telur ayam terutama telur ayam ras, telur itik (bebek) dan telur puyuh.

Untuk memperoleh telur yang berkualitas maka diperlukan pakan yang baik dalam menunjang tingkat produktifitas, pertumbuhan dan kesehatan, dibutuhkan kandungan nutrisi yang lengkap bagi ayam petelur berupa protein, lemak, kalsium, ME, fosfor, dan serat kasar. 
Kandungan nutrisi yang lengkap ini di butuhkan dalam jumlah yang tepat dan seimbang pada ransum. Terdapat beberapa factor yang mempengaruhi banyaknya kebutuhan nutrisi pada ayam petelur seperti, berat ayam dan produksi telur (Sudarmono.2003).

Salah satu bahan pakan alternatif yang dapat digunakan sebagai sumber protein, energi mineral, zat besi, kalsium dalam ransum dan memberikan peluang cukup baik adalah tepung roti yang berasal dari roti yang telah kadaluarsa, kemudian roti-roti tersebut ditarik dari pasaran. Apabila tidak termanfaatkan maka roti tersebut menjadi produk yang terbuang oleh pabrik dan akan mencemari lingkungan. Bahan dasar roti adalah $90 \%$ tepung terigu dan bahan lain seperti telur, susu sehingga kandungan proteinnya cukup tinggi, selain itu roti juga mengandung beta karotin, thiamin (vit $B_{1}$ ), riboflavin (vit $B_{2}$ ), niasin, mineral, zat besi dan kalsium (Astawan, 2007).

Laboratorium Nutrisi Ternak Ruminansia dan Kimia Makanan Ternak Fakultas Peternakan UNPAD (2007) melaporkan bahwa tepung limbah roti mengandung protein kasar 10,25\%, serat kasar $12,04 \%$, lemak kasar $13,42 \%$,kalsium $0,07 \%$, fospor $0,019 \%$, air $6,91 \%$ dan abu $0,80 \%$ serta energi metabolis yaitu $2952 \mathrm{kkal} / \mathrm{kg}$. Kandungan nutrisi tersebut maka tepung limbah roti dapat digunakan sebagai bahan pakan alternatif sumber energi, namun penggunaan dalam ransum ayam broiler perlu dibatasi karena mengandung serat kasar yang cukup tinggi. Ayam memiliki keterbatasan untuk mencerna serat kasar karena struktur anatomi saluran pencernaanya, yang memiliki caecum yang kecil. Atas dasar tersebut maka besarnya campuran serat kasar dalam ransum harus dibatasi yatu sekitar $8 \%$. Penggunaan tepung roti sebagai sumber energi 30 persen dapat menyumbang energi metabolis sekitar sekitar $30 \%$ energi metabolis ransum dan bila ditingkatkan penggunaan limbah roti tersebut sampai 50 persen akan meningkatkan juga kandungan serat kasar dan ini akan mengganggu performans ayam broiler. Serat kasar yang tinggi dapat membawa nutrisi yang dapat dicerna dari bahan pakan keluar bersama feeses sebelum sempat diserap usus (Wahyu, 1992).

\section{Bahan dan Metode}

Penelitian ini dilakukan di kandang pak Rozak alamat Pematang Gubernur RT 3, Kecamatan Muara Bangkahulu, Kota Bengkulu. Penelitian dilakukan selama 8 minggu mulai 22 Oktober 2019 sampai tanggal 20 Desember 2019.

\section{Pembuatan Tepung Roti Afkir}

Roti afkir yang diperoleh dari pabrik roti yang ada di Pekik Nyaring, Bengkulu Tengah, jenis roti yang diperoleh yaitu roti tradisional yang sudah kadaluarsa, kemudian roti dikumpulkan, dan dijemur hingga kering, kemudian digiling dan disimpan dalam karung.

\section{Persiapan kandang}

Sebelum penelitian dilakukan, kandang sudah harus dipersiapkan terlebih dahulu mulai dari kelengkapan kandang batteray seperti tempat minum dan tempat pakan, menyiapkan susunan ransum yang akan digunakan, serta menyiapkan segala kebutuhan kandang yang diperlukan dalam penelitian.

\section{Adaptasi Ternak}

Sebelum penelitian, ternak ayam ras petelur yang akan digunakan untuk penelitian diadaptasikan selama 4 hari dengan ransum perlakuan. Adaptasi dilakukan agar ternak terbiasa dengan pakan tersebut

\section{Rancangan Penelitian}

Penelitian ini menggunakan Rancangan Acak Lengkap (RAL) dengan ulangan yang tidak sama dengan 5 perlakuan dan 10 ulangan dimana masing-masing ulangan terdiri dari 1 ekor ayam. Ayam yang digunakan adalah ayam ras petelur coklat fase produksi umur 32 minggu. Jadi, total ternak yang digunakan adalah sebanyak 50 ekor ayam ras. Pengamatan penelitian ini dilakukan pada minggu kedua, keempat, keenam dan kedelapan.

Perlakuan yang diberikana sebagai berikut :

$\mathrm{PO}=$ Ransum kontrol $0 \%$ tepung roti afkir $\mathrm{P} 1=$ Ransum mengandung $10 \%$ tepung roti afkir P2 = Ransum mengandung $20 \%$ tepung roti afkir P3 = Ransum mengandung $30 \%$ tepung roti afkir P4 = Ransum mengandung $40 \%$ tepung roti afkir 
Ransum di formulasikan iso protein dan iso energy dengan kandungan PK $17 \%$ dan ME sebesar $2700 \mathrm{kkal} / \mathrm{kg}$ dengan menggunakan program LINDO.

\subsubsection{Pelaksanaan Penelitian}

Penelitian dilakukan selama 8 minggu, menggunakan ayam ras petelur fase produksi umur 32 minggu. Jumlah ayam yang digunakan sebanyak 50 ekor yang dipelihara dalam kandang batteray. Ternak diberi air minum secara adlibitum dan diberi makan 2 kali sehari dengan waktu pagi dan sore.

Sedangkan formulasi ransum yang digunakan selama penelitian disajikan pada Tabel 1.

\section{Variabel yang diamati}

\section{Berat Telur}

Berat telur diukur dengan menggunakan timbangan analitik dan cawan petri sebagai alasnya dalam satuan gram. Telur yang ditimbang sebanyak 50 butir, dimana nantinya akan dipecahkan di atas meja kaca.

\section{Kecerahan Yolk}

Warna yolk (kuning telur) diukur dengan menggunakan yolk colour fan setiap dua minggu sekali selama penelitian. Warna standar dengan skor 1-15 dari pucat sampai orange tua (pekat).

\section{Indeks Kuning Telur (IKT)}

Indeks kuning telur adalah perbandingan tinggi kuning telur dengan garis tengah kuning telur. Telur yang dipecahkan sebanyak 50 butir dan diletakkan di atas meja kaca, kemudian tinggi dan diameter kuning telur diukur dengan jangka sorong dengan bantuan alat kaki tiga dan dihitung dengan rumus (Koswara, 2009):

$$
\text { Indeks yolk }=\frac{\text { Tinggi yolk }}{\text { Garis Tengah yolk }}
$$

\section{Indeks Putih Telur (IPT)}

Indeks putih telur adalah perbandingan tinggi putih telur (albumen) kental dengan ratarata garis tengahnya. Telur yang dipecahkan sebanyak 50 butir dan diletakkan di atas meja kaca, kemudian tinggi dan diameter putih telur diukur dengan jangka sorong denagn bantuan alat kaki tiga dan dihitung dengan rumus (Koswara, 2009):

$$
\text { Indeks albumen }=\frac{\text { Tinggi albumen } \text { Kental }}{\text { Rata }- \text { Rata Garis Tengah albumen }}
$$

\section{Haugh Unit (HU)}

Haugh Unit (HU) adalah ukuran kualitas telur bagian dalam yang didapat dari hubungan antara tinggi putih telur dengan bobot telur. Telur yang dipecahkan sebanyak 50 butir. Nilai $\mathrm{HU}$ dihitung dengan rumus menurut Austic dan Nesheim (1990):

$$
\text { Nilai } H U=100 \log \left(H+7,57-1,7 \cdot W^{0,37}\right)
$$

$$
\begin{aligned}
& \text { Keterangan : } \\
& \mathrm{HU}=\text { Haugh Unit } \\
& \mathrm{H}=\text { Tinggi putih telur }(\mathrm{mm}) \\
& \mathrm{W}=\text { Bobot Telur }
\end{aligned}
$$

Tabel 1. Susunan ransum penelitian dan kandung nutrisinya

\begin{tabular}{lccccc}
\hline Bahan Pakan & P0 & P1 & P2 & P3 & P4 \\
\hline Jagung Kuning & 40,85 & 32,72 & 24,60 & 16,47 & 8,35 \\
Dedak & 22,43 & 19,60 & 16,76 & 13,92 & 11,08 \\
KLK & 34,72 & 35,68 & 36,64 & 37,60 & 38,57 \\
Tepung roti & 0 & 10 & 20 & 30 & 40 \\
Mineral mix & 1 & 1 & 1 & 1 & 1 \\
Top mix & 1 & 1 & 1 & 1 & 1 \\
\hline Total & $\mathbf{1 0 0}$ & $\mathbf{1 0 0}$ & $\mathbf{1 0 0}$ & $\mathbf{1 0 0}$ & $\mathbf{1 0 0}$ \\
\hline PK (\%) & 17,00 & 17,00 & 17,00 & 17,00 & 17,00 \\
ME (kkal/kg) & 2700 & 2700 & 2700 & 2700 & 2700 \\
SK (\%) & 4,71 & 4,14 & 3,56 & 2,98 & 2,41 \\
Ca (\%) & 4,12 & 4,23 & 4,33 & 4,43 & 4,54 \\
P (\%) & 0,86 & 0,83 & 0,80 & 0,76 & 0,73 \\
LK (\%) & 4,85 & 6,88 & 8,91 & 10,94 & 12,98 \\
\hline
\end{tabular}




\section{Tebal Kerabang}

Tebal kerabang telur diukur dengan alat mikrometer skrup setiap dua minggu sekali selama penelitian. Pengukuran ketebalan kerabang diukur dibagian tumpul, tengah, dan lancip. Dari ketiga bagian tersebut dirataratakan.

\section{Analisis Data}

Data hasil percobaan dianalisis keragamannya dengan Analisis Varians (ANOVA) dan jika menunjukkan pengaruh yang nyata $(P<0,05)$ maka dilanjutkan dengan Duncan's Multiple Range Test (DMRT)..

\section{HASIL DAN PEMBAHASAN}

\section{Berat Telur}

Berat telur pada ayam ras petelur sangat penting untuk menentukan tingkat harga penjualan di pasar. Hal ini dikarenakan telur dengan ukuran yang lebih besar harganya relative lebih mahal dibandingkan dengan telur dengan ukuran kecil. Nilai rataan berat telur dari minggu kedua sampai minggu kedelapan selama penelitian dapat dilihat pada Tabel 2 .

Hasil analisis ragam menunjukkan bahwa pemberian tepung roti afkir dalam ransum tidak berpengaruh nyata terhadap rata-rata berat telur pada minggu kedua, keempat, keenam, kedelapan dan selama penelitian $(P>0,05)$. (Lampiran 1-10).

Berdasarkan berta telur menurut SNI 013926-2006 berat telur ayam ras dikelompokkan menjadi 5 yaitu ekstra besar ( $>60 \mathrm{~g}$ ), besar (56$60 \mathrm{~g}$ ), sedang (51-55 g), kecil (<46 g). Maka rataan berat telur yang diperoleh selama penelitian pada ransum kontrol dan perlakuan tepung roti adalah termasuk kategori besar karena rata-rata berat telur yang dihasilhan lebih besar dari 56 gram. Pemberian tepung roti dengan level $10 \%$ sampai $40 \%$ tidak berdampak negatif terhadap berat telur ayam yang dihasilkan. Wahyu (1997), menyatakan bahwa banyak faktor yang mempengaruhi berat telur diantaranya adalah genetik, dewasa kelamin, umur, beberapa obat-obatan dan beberapa zat makanan dalam ransum. Pada penelitian ini menggunakan jenis dan umur ayam yang sama, tepung roti dengan level yang berbeda dengan kandungan protein kasar yang sama $17 \%$ dan metabolism energy sebesar $2700 \mathrm{Kkal} / \mathrm{kg}$. Hal ini menunjukkan bahwa ransum yang diberikan memiliki nutrisi yang relative sama, sehingga tidak terdapat perbedaan berat telur antara kelompok P0, P1, P2, P3 dan P4.

Tabel 2. Pengaruh penggunaan tepung roti afkir dalam ransum terhadap berat telur

\begin{tabular}{ccccccc}
\hline \multirow{2}{*}{ Minggu ke } & \multicolumn{5}{c}{ Berat Telur } & \multirow{2}{*}{$\mathrm{P}$} \\
\cline { 2 - 5 } & $\mathrm{P} 0$ & $\mathrm{P} 1$ & $\mathrm{P} 2$ & $\mathrm{P} 3$ & $\mathrm{P} 4$ & 0,74 \\
\hline 2 & 57,30 & 58,20 & 58,22 & 56,00 & 58,40 & 0,76 \\
4 & 56,50 & 58,40 & 58,44 & 57,60 & 58,30 & 0,37 \\
6 & 56,50 & 59,70 & 59,22 & 58,50 & 59,60 & 0,52 \\
\hline Rata-rata & 56,70 & 59,00 & 58,89 & 59,10 & 59,40 & 0,59 \\
\hline Sd & 56,75 & 58,83 & 58,69 & 57,80 & 58,93 & 0,30 \\
\hline
\end{tabular}

Keterangan : $P O=$ Ransum kontrol, $P 1=$ Penggunaan 10\% TRA, $P 2=$ Penggunaan 20\% TRA, P3 = Penggunaan 30\% TRA, $P 4=$ Penggunaan 40\% TRA, $P>0,05=$ Tidak berpengaruh nyata

Tabel 3. Pengaruh penggunaan tepung roti afkir dalam ransum terhadap warna yolk telur

\begin{tabular}{ccccccc}
\hline \multirow{2}{*}{ Minggu ke } & \multicolumn{5}{c}{ Warna Yolk } & \multirow{2}{*}{$\mathrm{P}$} \\
\cline { 2 - 5 } & $\mathrm{P} 0$ & $\mathrm{P} 1$ & $\mathrm{P} 2$ & $\mathrm{P} 3$ & $\mathrm{p} 4$ & \\
\hline 2 & $7,10^{\mathrm{ab}}$ & $7,80^{\mathrm{a}}$ & $6,33^{\mathrm{b}}$ & $5,60^{\mathrm{bc}}$ & $4,80^{\mathrm{c}}$ & 0,00 \\
4 & $7,80^{\mathrm{a}}$ & $7,60^{\mathrm{a}}$ & $6,22^{\mathrm{b}}$ & $5,40^{\mathrm{b}}$ & $4,10^{\mathrm{c}}$ & $1,0 \mathrm{E}-10$ \\
6 & $7,10^{\mathrm{ab}}$ & $7,80^{\mathrm{a}}$ & $6,33^{\mathrm{b}}$ & $5,60^{\mathrm{bc}}$ & $4,80^{\mathrm{c}}$ & 0,00 \\
8 & $8,20^{\mathrm{a}}$ & $7,00^{\mathrm{b}}$ & $6,33^{\mathrm{c}}$ & $4,80^{\mathrm{d}}$ & $3,90^{\mathrm{e}}$ & $1,1 \mathrm{E}-18$ \\
\hline Rata-rata & $7,55^{\mathrm{a}}$ & $7,55^{\mathrm{a}}$ & $6,31^{\mathrm{b}}$ & $5,35^{\mathrm{c}}$ & $4,40^{\mathrm{d}}$ & $3,08 \mathrm{E}-12$ \\
\hline Sd & 0,54 & 0,38 & 0,06 & 0,38 & 0,47 & \\
\hline
\end{tabular}

Keterangan : $P O=$ Ransum kontrol, $P 1=$ Penggunaan $10 \%$ TRA, $P 2=$ Penggunaan $20 \%$ TRA, P3 = Penggunaan 30\% TRA, $P 4=$ Penggunaan 40\% TRA, $P>0,05=$ Tidak berpengaruh nyata, $P<0,05=$ Berpengaruh nyata, $P<0,01=$ Sangat berpengaruh nyata. 


\section{Warna Yolk}

Hasil rataan warna yolk dari minggu kedua sampai minggu kedelapan dan rataan selama penelitian dapat dilihat pada Tabel 3.

Hasil analisis ragam menunjukkan bahwa penggunaan tepung roti dalam ransum berpengaruh sangat nyata $(P<0,01)$ terhadap rataan warna yolk pada minggu kedua, keempat, keenam, kedelapan, dan rataan selama penelitian. (Lampiran 11-24).

Semakin tinggi penggunaan tepung roti afkir warna kuning yolk semakin menurun dari minggu ke 2 sampai munggu ke 8 . Hal ini dikarenakan semakin tinggi penggunaan tepung roti penggunaan jagung pada susunan ransum semakin sedikit sehingga menyebabkan warna yolk menjadi pucat. Peningkatan warna yolk disebabkan oleh pigmen xantofil atau kandungan $b$-karoten yang terdapat pada jagung. Hal ini menunjukkan bahwa skor warna yolk pada penelitian ini lebih besar di pengaruhi oleh jagung yang dikandung dalam pakan. Peningkatan level penggunaan tepung roti pada pakan dapat menurunkan skor warna yolk, semakin tinggi pemberian tepung roti pada pakan, maka warna yolk semakin pucat.

Tinggi rendahnya warna yolk dipengaruhi oleh sejumlah kandungan pigmen warna dalam ransum yang disebut karotenoitd (Sudaryani, 2003). Warna kuning telur yang baik berada pada kisaran 7-12 (Amrullah, 2004). Karoten banyak terkandung dalam pigmen xantofil, sedangkan pigmen xantofil banyak terdapat pada jagung. Pencampuran jagung pada formulasi ransum ayam petelur selain bertujuan sebagai sumber energy juga merupakan sumber karoten pada pembentukan warna kuning telur (Hongadi.2009).

\section{Indeks Yolk atau Indeks Kuning Telur (IKT)}

Indeks yolk atau indeks kuning telur (IKT) adalah perbandingan tinggi kuning yolk dengan garis tengah yolk. Hasil perhitungan rataan indeks yolk pada minggu kedua sampai minggu kedelapan dan selama penelitian dapat dilihat pada Tabel 4.

Hasil analisis ragam menunjukkan bahwa penggunaan tepung roti afkir dalam ransum tidak berpengaruh nyata $(P>0,05)$ terdapat

Tabel 4. Pengaruh penggunaan tepung roti afkir dalam ransum terhadap rataan indeks yolk ayam ras.

\begin{tabular}{ccccccc}
\hline \multirow{2}{*}{ Minggu ke } & \multicolumn{7}{c}{ Indeks Yolk } & \multirow{2}{*}{ Probabilitas } \\
\cline { 2 - 6 } & P0 & P1 & P2 & P3 & P4 & \\
\hline 2 & 0,46 & 0,47 & 0,47 & 0,48 & 0,49 & 0,23 \\
4 & 0,43 & 0,44 & 0,43 & 0,44 & 0,42 & 0,58 \\
6 & 0,45 & 0,46 & 0,45 & 0,46 & 0,45 & 0,88 \\
8 & $0,48^{\text {ab }}$ & $0,51^{\mathrm{a}}$ & $0,51^{\mathrm{a}}$ & $0,51^{\mathrm{a}}$ & $0,47^{\mathrm{b}}$ & 0,02 \\
\hline Rata-rata & 0,46 & 0,47 & 0,46 & 0,47 & 0,46 & 0,18 \\
\hline Sd & 0,02 & 0,03 & 0,04 & 0,03 & 0,03 & \\
\hline
\end{tabular}

Keterangan : $P O=$ Ransum kontrol, P1 = Penggunaan 10\% TRA, P2 = Penggunaan 20\% TRA, P3 = Penggunaan 30\% TRA, $P 4=$ Penggunaan 40\% TRA, $P>0,05=$ Tidak berpengaruh nyata, $P<0,05=$ Berpengaruh nyata

Tabel 5. Pengaruh penggunaan tepung roti afkir dalam ransum terhadap indeks putih telur ayam ras.

\begin{tabular}{ccccccc}
\hline \multirow{2}{*}{ Minggu ke } & \multicolumn{7}{c}{ Indeks Albumen } & \multirow{2}{*}{ Probabilitas } \\
\cline { 2 - 5 } & $\mathrm{P} 0$ & $\mathrm{P} 1$ & $\mathrm{P} 2$ & $\mathrm{P} 3$ & $\mathrm{p} 4$ & \\
\hline 2 & 0,082 & 0,081 & 0,084 & 0,089 & 0,077 & 0,55 \\
4 & 0,086 & 0,088 & 0,089 & 0,085 & 0,081 & 0,59 \\
6 & 0,090 & 0,083 & 0,092 & 0,093 & 0,087 & 0,30 \\
8 & 0,092 & 0,088 & 0,093 & 0,096 & 0,083 & 0,10 \\
\hline Rata-rata & 0,087 & 0,085 & 0,089 & 0,091 & 0,082 & 0,30 \\
\hline Sd & 0,004 & 0,003 & 0,004 & 0,004 & 0,004 & \\
\hline
\end{tabular}

Keterangan : $P 0=$ Ransum kontrol, $P 1=$ Penggunaan $10 \%$ TRA, $P 2=$ Penggunaan 20\% TRA, $P 3=$ Penggunaan 30\% TRA, $P 4=$ Penggunaan 40\% TRA, $P>0,05=$ Tidak berpengaruh nyata, $P<0,05=$ Berpengaruh nyata 
Tabel 6. Pengaruh penggunaan tepung roti afkir dalam ransum terhadap nilai haugh unit

\begin{tabular}{ccccccc}
\hline \multirow{2}{*}{ Minggu ke } & \multicolumn{7}{c}{ Haugh Unit } & \multirow{2}{*}{ Probabilitas } \\
\cline { 2 - 6 } & P0 & P1 & P2 & P3 & p4 & 0,65 \\
4 & 92 & 94 & 95 & 96 & 92 & 0,16 \\
6 & 96 & 98 & 98 & 95 & 94 & 0,27 \\
8 & 99 & 96 & 99 & 99 & 97 & 0,12 \\
\hline Rata-rata & 97 & 99 & 99 & 100 & 96 & 0,39 \\
\hline Sd & 3,60 & 2,22 & 1,94 & 2,49 & 1,88 & \\
\hline
\end{tabular}

Keterangan : $P O=$ Ransum kontrol, $P 1=$ Penggunaan 10\% TRA, $P 2=$ Penggunaan 20\% TRA, $P 3=$ Penggunaan 30\% TRA, P4 = Penggunaan 40\% TRA, $P>0,05=$ Tidak berpengaruh nyata, $P<0,05=$ Berpengaruh nyata

indeks yolk pada minggu kedua, keempat, keenam, dan rataan selama penelitian. Sedangkan minggu kedelapan berpengaruh nyata terhadap indeks kuning telur $(P<0,05)$. (Lampiran 25-35).

Hasil uji lanjut minggu kedelapan PO tidak berbeda nyata dengan P1, P2, P3, dan P4. Sedadangkan $\mathrm{P} 1$ tidak berbeda nyata dengan $\mathrm{P} 2$ dan P3, namun berbeda nyata dengan P4 dan P2 tidak berbeda nyata dengan $\mathrm{P3}$, namun berbeda dengan nyata dengan P4. Berdasarkan hasil rataan data selama penelitian di atas, pemberian tepung roti afkir tidak memeberikan pengaruh yang berbeda terhadap indeks kuning telur $(P>0,05)$. Hal ini menunjukkan pemberian tepung roti afkir tidak berdampak negatif terhadap indeks kuning telur. Hal ini dapat dilihat pada data bahwa indeks kuning telur yang dihasilkan masih berada pada kisaran normal. Koswara (2009) menyatakan telur yang segar mempunyai indeks yolk 0,33-0,50 dengan ratarata 0,42. Argo et al. (2013) menyatakan bahwa indeks yolk dipengaruhi oleh protein, lemak, dan asam amino esensial yang terkandung dalam pakan, faktor lain yang mempengaruhi indeks yolk antara lain ukuran telur, lama penyimpanan, suhu, kualitas membrane vitelin, dan nutrisi pakan. Menurut Wilson (1975) protein pakan akan mempengaruhi viskositas telur yang mencerminkan kualitas interior telur, selanjutnya dapat mempengaruhi indeks yolk

\section{Indeks Putih Telur (IPT)}

Indeks putih telur adalah perbandingan tinggi putih telur (albumen) kental denagn ratarat garis tengahnya. Hasil perhitungan rataan indeks putih telur pada minggu kedua sampai minggu kedelapan dan selama penelitian dapat dilihat pada Tabel 5.

Berdasarkan pada Tabel 2 menunjukkan bahwa jumlah periode sapi perah di Kecamatan Kabawetan Kabupaten Kepahiang yang paling rendah kepemilikan pedet 2,31 (UT) dengan persentase $8,27 \%$ dan yang paling tinggi kepemilikan indukan 23 (UT) dengan persentase 82,29\%. Tabel 2 menunjukkan bahwa jumlah kepemilikan ternak sapi perah responden di Kecamatan Kabawetan Kabupaten Kepahiang masih berskala sedang. Hal ini terlihat dari 93,3\% responden yang memiliki 1-2 UT sapi perah. Hal ini sesuai pendapat Rasali et al. (2013) yang menyatakan bahwa lebih dari 90\% berupa peternakan rakyat yang memiliki ciri skala usaha relatif kecil berkisar antara 1-5 ekor. Besar atau kecil jumlah kepemilikan ternak yang dimiliki oleh peternak sangatlah membantu dalam meningkatkan pendapatan dan pemenuhan kebutuhan. Hal ini sejalan dengan pendapat Paturochman (2005) yang menyatakan bahwa besar kecilnya kepemilikan ternak sangat mempengaruhi tingkat pendapatan, jadi makin tinggi kepemilikan ternak maka makin besar tingkat pendapatan peternak.

Hasil analisis ragam menunjukkan bahwa pemberian tepung roti afkir pada ayam ras memberikan pengaruh tidak nyata $(P>0,05)$ pada minggu kedua, keempat, keenam, kedelapan dan hasil rataan selama penelitian. (Lampiran 36-45).

Pemberian tepung roti afkir tidak berdampak negatif terhadap indeks putih telur hal ini dapat dilihat pada data bahwa indeks putih telur yang dihasilkan $(0,82-0,91)$ masih berada pada kisaran normal. Menurut Winarno dan Koswara (2002) bahwa telur segar memiliki 
Tabel 7. Pengaruh penggunaan tepung roti afkir dalam ransum terhadap tebal kerabang telur ayam ras.

\begin{tabular}{ccccccc}
\hline \multirow{2}{*}{ Minggu ke } & \multicolumn{5}{c}{ Tebal Kerabang } & \multirow{2}{*}{$\mathrm{P}$} \\
\cline { 2 - 5 } & $\mathrm{P} 0$ & $\mathrm{P} 1$ & $\mathrm{P} 2$ & $\mathrm{P} 3$ & $\mathrm{p} 4$ & 0,99 \\
\hline 2 & 0,36 & 0,40 & 0,37 & 0,37 & 0,35 & 0,62 \\
4 & 0,38 & 0,37 & 0,38 & 0,38 & 0,37 & 0,20 \\
6 & 0,40 & 0,41 & 0,41 & 0,39 & 0,40 & 0,50 \\
\hline 8 & 0,41 & 0,42 & 0,41 & 0,41 & 0,40 & 1,00 \\
\hline Rata-rata & 0,39 & 0,40 & 0,39 & 0,39 & 0,38 & 0,02 \\
\hline
\end{tabular}

Keterangan : $P O=$ Ransum kontrol, $P 1=$ Penggunaan 10\% TRA, $P 2=$ Penggunaan 20\% TRA, $P 3=$

Penggunaan 30\% TRA, P4 = Penggunaan 40\% TRA, P>0,05 = Tidak berpengaruh nyata

indeks putih telur yaitu 0,050-0,174 $\mathrm{mm}$. Menurut Sudaryani (2003) menyatakan bahwa semakin banyak kandungan protein dalam pakan, maka akan menghasilkan putih telur yang lebih kental, semakin kental putih telur maka semakin tinggi indeks putih telur tersebut.

Penurunan indeks putih telur disebkan oleh penguapan gas $\mathrm{CO} 2$ dan air dalam telur sehingga sifat basa dari putih telur naik kemudian menyebabkan serabut ovomucin menjadi rusak. Wilson (1975) menyatakan bahwa indeks putih telur dipengaruhi oleh protein pakan. Protein pakan akan mempengaruhi viskositas telur yang mencerminkan kualitas internal telur, selanjutnya dapat mempengaruhi indeks putih telur.

\section{Haugh Unit (HU)}

Haugh unit adalah nilai yang mencerminkan keadaan albumen untuk menentukan kualitas telur. Nilai HU ditentukan berdasarkan keadaan albumen, yaitu perbandingan antara tinggi putih dan berat telur. Hasil perhitungan nilai rataan haugh unit telur pada minggu kedua sampai minggu kedelapan dapat dilihat pada Tabel 6 .

Hasil analisis ragam menunjukkan bahwa penggunaan tepung roti afkir dalam ransum pada minggu kedua, keempat, keenam, kedelapan dan rataan selama penelitian memeberikan pengaruh tidak nyata $(P>0,05)$. (Lampiran 46-55).

Berdasarkan hasil analisis ragam rataan haugh unit telur tidak memberikan pengaruh nyata $(P>0,05)$ hal ini menunjukkan pemberian tepung roti afkir tidak berdampak negatif terhadap nilai haugh unit telur. USDA (2000) HU telur dengan kualitas AA (72 sampai 100), B (6071), C (dibawah 29). Maka berdasarkan hasil penelitian dapat disimpulkan bahwa nilai $\mathrm{HU}$ telur P0, P1, P2, P3 dan P4 pada minggu kedua sampai minggu kedelapan dan rataan selama penelitian termasuk dalam kualitas $A A$, yaitu nilai rata-rata $\mathrm{HU}$ yang diperoleh berkisar antara 95-98. Artinya, telur yang diuji dalam keadaan segar dan memiliki albumen yang kental sehingga korelasi antara albumen dengan bobot telur tinggi.

\section{Tebal Kerabang}

Tebal kerabang diukuran pada bagian tumpul, tengah, dan lancip. Dari ketiga bagian tersebut kemudian dirata-ratakan. Hasil pengukuran rataan tebal kerabang dari minggu kedua sampai minggu kedelapan dan selama penelitian dapat dilihat pada Tabel 7. Hasil analisis ragam menunjukan bahwa pemberian tepung roti afkir dalam ransum pada minggu kedua, keempat, keenam, kedelapan, dan rataaan berpengaruh tidak nyata $(P>0,05)$ tehadap tebal kerabang. (Lampiran 56-64). Hal ini menunjukkan pemberian tepung roti afkir tidak berdampak negative terhadap tebal kerabang. Yuanta (2004) menyatakan bahwa tebal kerabang telur ayam yang baik berkisar antara 0,33-0,35 $\mathrm{mm}$. Tebal kerabang yang dihasilkan pada penelitian ini berkisar antar $0,39-0,40 \mathrm{~mm}$. Maka tebal kerabang yang diperoleh termasuk standar ukuran normal tebal kerabang. Penggunaan tepung roti dalam ransum tidak berpengaruh nyata terhadap tebal kerang, hal ini dikarenakan $\mathrm{Ca}$ dan $\mathrm{P}$ dalam ransum pada masing-masing perlakuan hampir sama. Factor yang mempengaruhi kualitas kerabang telur yaitu ketebalan dan struktur kerabang. Pakan yang mengandung $\mathrm{Ca}, \mathrm{P}$, dan ion karbonat sangat mempengaruhi proses pembentukan kualitas kerang telur (Anggrodi, 
2009). Semakin tinggi kualitas kalsium maka kualitas kerabang telur semakin baik (Clunies et
Peningkatan ukuran rungga udara menurut (Jazil et al., 2013) disebabkan oleh penyusutan berat

Tabel 8. Pengaruh penggunaan tepung roti afkir dalam ransum terhadap kedalaman rongga udara telur ayam ras.

\begin{tabular}{ccccccc}
\hline \multirow{2}{*}{ Minggu ke } & \multicolumn{5}{c}{ Rongga Udara } & \multirow{2}{*}{$\mathrm{P}$} \\
\cline { 2 - 5 } & $\mathrm{P} 0$ & $\mathrm{P} 1$ & $\mathrm{P} 2$ & $\mathrm{P} 3$ & $\mathrm{p} 4$ & \\
\hline 2 & 2,59 & 2,41 & 2,56 & 2,45 & 2,47 & 0,97 \\
4 & 2,54 & 2,24 & 2,57 & 2,18 & 2,46 & 0,49 \\
6 & 2,79 & 2,55 & 2,74 & 2,66 & 2,55 & 0,60 \\
8 & 3,05 & 2,88 & 2,86 & 2,74 & 2,56 & 0,65 \\
\hline Rata-rata \pm Sd & 2,74 & 2,52 & 2,68 & 2,51 & 2,51 & 0,39 \\
\hline Sd & 0,23 & 0,27 & 0,15 & 0,25 & 0,05 & \\
\hline
\end{tabular}

Keterangan : $P O=$ Ransum kontrol, $P 1=$ Penggunaan 10\% TRA, $P 2=$ Penggunaan 20\% TRA, $P 3=$ Penggunaan 30\% TRA, $P 4=$ Penggunaan 40\% TRA, $P>0,05=$ Tidak berpengaruh nyata, $P<0,05=$ Berpengaruh nyata

al., 1992).

Muharlien dan Natsir. (2011) menyatakan kekurangan kalsium dan phosphor dalam pakan menghasilkan kerabang telur yang titis yang mengakibatkan telur mudah retak dan menyebabkan bakteri mudah masuk kebagian dalam telur. Rahadianto et al., (2013) juga menyatakan tebal kerabang juga dipengaruhi oleh vitamin D. kadar vitamin D yang cukup diperlukan untuk mengabsorbsi kalsium dalam proses pembentukan tebal kerabang. Kerabang telur merupakan bagian terluar dari telur dan penting untuk diperhatikan kualitasnya, karena kerabang telur berfungsi melindungi isi telur dari masuknya bakteri penyebab kerusakan isi telur yang dapat mengakibatkan menurunnya kualitas telur (Amo et al., 2013)

\section{Tinggi Rongga Udara}

Hasil perhitungan rataan tinggi rongga udara minggu kedua sampai minggu kedelapan dan selama penelitian di sajikan pada Tabel 8 .

Hasil analisis ragam menunjukan bahwa pemberian tepung roti afkir dalam ransum pada minggu kedua, keempat, keenam, kedelapan dan rataan selama penelitian berpengaruh tidak nyata $(P>0,05)$ terhadap kedalaman rongga udara. (Lampiran 65-75).

Kedalaman rongga udara yang baik yaitu lebih kecil atau sama dengan tiga milimeter, artinya semakin besar rongga udara, kualitas telur semakin berkurang (Hadiwiyoto, 1983). Dapat dilihat pada tabel 8 . Kedalaman rongga udara telur pada penelitian ini tergolong normal dan dapat dikatakan kualitasnya baik. telur yang diakibatkan penguapan air dan pelepasan gas yang terjadi selama penyimpanan. Seiring bertambahnya umur, telur akan kehilangan cairan dan isinya semakin menyusut sehingga memperbesar rongga udara. BSN (2008) menyatakan bahwa telur segar memiliki rata-rata kedalaman rongga udara sebesar 2,19 mm (mutu I), 5,69 ( mutu II) 1 minggu penyimpanan, dan $8,52 \mathrm{~mm}$ (mutu III) 2 minggu penyimpanan. Selama dilakukan penelitian, kedalaman rongga udara berada pada mutu I dengan nilai 2,51-2,74 karena telur yang digunakan yaitu telur yang baru berumur satu hari sehingga rongga udara masih kecil.

\section{Kesimpulan}

Berdasarkan hasil penelitian dapat disimpulkan bahwa penggunaan tepung roti afkir level 10\%, 20\%, 30\% dan 40\% dalam ransum ayam ras dapat menurunkan warna yolk, tetapi tidak menurunkan berat telur, indeks kuning telur, indeks putih telur, haugh unit, tebal kerabang dan rongga udara.

\section{Daftar Pustaka}

Alfi, M. 2009. Pengaruh Penggunaan Tepung Roti Afkit Sebagai Pengganti Jagung dalam Ransum terhadap Produksi Karkas Ayam Broiler Jantan. Universitas Diponegoro., Semarang.

Austic, R. E. and M. C. Nesheim. 1990. Poultry Production. 13th Ed. Lea and Febiger,Philadelphia. 
Astawan, M. 2007. Kandungan serat dan Gizi pada Roti Unggul Mie dan Nasi. Kompas Cyber Media, Bogor.

Ambrullah, I. K. 2004. Nutrisi Ayam Petelur. Lembaga Satu Gunungbudi. Bogor.

Amo, M., J. L. P. Saerang, M. Najoan dan J. Keintjem. 2013. Pengaruh penambahan tepung kunyit (Curcuma domestica Val) dalam ransum terhadap kualitas telur puyuh (Coturnix-coturnix japonica). Jurnal Zootek.33 (1) 8-57

Anggrodi, R. 2009. Kemajuan Mutakhir dalam IImu Makanan Ternak Unggas. UI press. Jakarta.

Argo, L.B., Tristiarti, dan I. Mangisah. 2013. Kualitas Fisik Telur Ayam Arab Petelur Fase I Dengan Berbagai Level Azolla microphylla. Animal Agricultural journal. Vol. 2 (1): 445447.

Badan Standarisasi Nasional (BSN). 2008. SNI 3926:2008 Telur Ayam Konsumsi. BSN. Jakarta.

Clunies, M. D. Parks and S. Lesson. 1992. Calcium and phosphorus metabolism ang egg shell formation of hens fed differendt amounts of calcim. Poultry science.71: 482-489.

Buckle, K. A., R. A.Edwards., G. H. Fleedrds., dan M. Wooton. 2007. Ilmu Pangan. Terjemahan hari purnomo dan adiono.ui press. Jakarta.

Gaol, S. E. L., Lisnawaty S., lis Y., 2015. Substitusi Ransum Jadi dengan Roti Afkir Terhadap Performa Burung Puyuh (Coturnix coturnix japonica) Umur Starter Sampai Awal Bertelur. Program Studi Peternakan Fakultas Pertanian Universitas Palangka Raya. Jurnal Ilmu Hewani Tropika Vol 4. No. 2

Hadiwiyoto, S. 1983. Hasil-Hasil Olahan Susu, Ikan, Daging dan Telur. Liberty. Yogyakarta.

Hartadi, H., S. Reksohadhiprojo, dan A. D. Tilman. 2005. Table Komposisi Pakan untuk Indonesia. Gadjah Mada Universiti press. Yogyakarta.

Hidayatullah, M.F., Irfan dan N. Halim. 2012. Efek Penggunaan Tepung Limbah Roti Tawar Sebagai Pengganti Jagung Terhadap Penampilan Produksi Itik Hibrida. Jurnal
Fakultas Peternakan Universitas Brawijaya. Malang.

Hongadi, P. 2009. Konsultasi Kuning Telur Pucat. http://info.medion.co.id. Diakses pada 8 juni 2020.

Jazil, N., A. Hintono, S. Mulyani. 2013. Penurunan Kualitas Telur Ayam Ras Dengan Intensitas Warna Coklat Kerabang Berbeda Selama Penyimpanan. Jurnal aplikasi teknologi pangan. Vol. 2 (1) : 43-47.

Koswara, S. 2009. Teknologi Pengolahan Telur (Teori Dan Praktek). eBook Pangan.com. Diakses 8 Juni 2020.

Kurtini, T. dan Rr. Riyanti. 2011. Ilmu Produksi Ternak Unggas. Penuntun Praktikum. Universitas Lampung. Bandar Lampung.

Laboratorium IImu Nutrisi Dan Pakan Ternak. 2013. Hasil Analisis Roti Afkir. Program Studi Peternakan FP USU. Medan.

Laboratorium Nutrisi Ternak Ruminansia dan Kimia Makanan Ternak. 2007. Fakultas Peternakan UNPAD.

Muharlien. 2010. Meningkatkan Kualitas Telur Melalui Penambahan Teh Hijau Dalam Pakan Ayam Petelur. Jurnal IImu dan Teknologi Hasil Ternak. Vol. 5(1) : 32-37.

Muharlien, V dan M. H. Natsir. 2011. Efek Penambahan Tepung Kulit Nanas (Ananas Comosus (L) Merr.) Dalam Pakan Terhadap Jumlah Telur Dan Kualitas Telur Itik. Jurnal Ilmu Dan Teknologi Hasil Ternak 6(2): 4-14.

Neesheim, M. C.,R.E.Austic., and L.E.Card 1997. Poultry Production. Lea and Febiger, Philadelphia.

Rahadianto, A., O. Sjofjan dan I. H. Djunaidi. 2013. Efek Penambahan Beberapa Sumber Kalsium Dalam Pakan Terhadap Kualitas Eksternal Telur Ayam Petelur. Fakultas Peternakan Universitas Brawijaya. Malang.

Sarwono, B. 2001. Pengawetan dan Pemanfaatan Telur. Penebar Swadaya. Jakarta

Seliem, H.P., EM. Lakolo, T.B.Purwantini, M. Ariani dan Y. Marisa. 2001. Analisis Ketahanan Pangan Tingkat Rumah Tangga Dan Regional. Laporan 36 Hasil Penelitian. 
Pusat Penelitian dan Pengembangan Social Ekonomi Pertanian. Bogor.

Sudaryani., T. 2003. Kualitas Telur. Penebar Swadaya. Cetakan ke-4. Jakarta.

Sudarmono, A.S. 2003. Pedoman Pemeliharaan Ayam Ras Petelur. Jakarta. Penerbit Kanisius. Hal : 22; 49; 64-82.

Unitet States Departement of Agriculture. 2000. Egg Grading Manul. Agricultural Handbook number 75. Washington DC.

Wahyu, J. 1992. Ilmu Nutrisi Unggas. Gadjah Mada University Press. Yogyakarta.

Wahyu, J. 1997. Ilmu Nutrisi Unggas. Gadjah Mada University Press, Yogyakarta.

Widjastuti, T.dan Endang S. 2007. Pemanfaatan Tepung Limbah Roti Dalam Ransum Ayam Broiler dan Implikasinya Terhadap Efisien Ransum Serta Icone Over Feed and Chick
Cost. Seminar nasional Pengembangan Sistem Reproduksi dan Pemanfaatan Sumber Daya Lokal Untuk Kemandirian Program Asal Hewan. Hal 558-561. Fakultas Peternakn. Universitas Padjadjaran Bandung.

Wilson, B. J. 1975. The performance of male ducklings given starter diets with different concentration of energy and protein. British poultry science. 16 : 625-657.

Winarno, F. G., dan S. Koswara.2002. Telur : Komposisi, Pengamatan dan Pengolahannya. M W Brio Press, Bogor.

Yuwanta, T. 2004. Dasar Ternak Uggas. Penerbit Kanisius. Yogyakarta.

Yuwanta, T. 2010. Telur Dan Kualitas Telur. Gadjah Mada University Press. Yogyakarta 